\title{
PROFIL KOMUNIKASI ANTARBUDAYA MAHASISWA BIMBINGAN DAN KONSELING
}

\author{
Uray Herlina ${ }^{1}$
}

\begin{abstract}
Communication is an essential tool for humans in fulfil the necessities of life and to attain the purpose of it. Communication and culture are two things that can not be separated like two sides of a coin. Studying communication means learn the culture, and viceversa. The purpose if this research to describe the profile of intercultural communication to students. The instrument that used was the inventory Guttman scale. Respondents of this research are students of IKIP PGRI Pontianak from every level of I, III, and V semester, with the total number of respondents are 66 people. The results showed in generally that the profile of intercultural communication among students has been good, where the cognitive, affective and psychomotor of student in every level of semester and ethnic are not much different. Hopefully this research can be the foundation of the development of communication skills counseling on student guidance and counseling. Proper communication will bring success in relationship counseling for counselors and clients who come from different cultures.
\end{abstract}

Keywords: Affective, Cognitive, Intercultural Communication, Psychomotor, Students.

JOMSIGN: Journal of Multicultural Studies in Guidance and Counseling Website : http://ejournal.upi.edu/index.php/JOMSIGN

Permalink: http://ejournal.upi.edu/index.php/JOMSIGN/article/view/6287

How to cite (APA): Herlina, U. (2017). Profil komunikasi antarbudaya mahasiswa bimbingan dan konseling JOMSIGN: Journal of Multicultural Studies in Guidance and Counseling, 1(2), 123-138.

This is an open access article distributed under the terms of the Creative Commons Attribution 4.0 International License, which permits unrestricted use, distribution, and reproduction in any medium, provided the original work is properly cited.

\section{PENDAHULUAN}

Pendidikan adalah suatu proses yang menjadikan manusia dari apa adanya menjadi bagaimana seharusnya (Kartadinata, 2014, p. 1), maka hal ini sudah sepantasnya menjadi tanggung jawab bersama semua komponen dalam negara untuk memberikan pendidikan yang tepat. Manusia adalah unsur yang sangat menentukan terselenggaranya pendidikan yang efektif dan efisien (Sadulloh, 2015, p. 127) oleh karena itu penting bagi semua orang untuk terlibat dalam pendidikan sejak anak masih kecil hingga dewasa, baik di lingkungan keluarga,

\footnotetext{
${ }^{1}$ IKIP PGRI Pontianak, Indonesia; ainauray@yahoo.co.id.
} 
sekolah dan masyarakat atau lingkungan sosial-budayanya (Rasyidin, 2014, p. 175).

Upaya Bimbingan dan Konseling (BK) dalam merealisasikan fungsi-fungsi pendidikan, terarah pada upaya membantu individu untuk mencapai tingkat perkembangan diri secara optimum di dalam menavigasi hidupnya secara mandiri (Kartadinata, 2011, p. 57). BK saat ini merupakan kebutuhan yang tidak bisa terelakkan dalam pendidikan. Layanan BK adalah upaya sistematis, objektif, logis, dan berkelanjutan serta terprogram yang dilakukan oleh konselor atau guru BK untuk memfasilitasi perkembangan peserta didik/konseli untuk mencapai kemandirian, dalam wujud kemampuan memahami, menerima, mengarahkan, mengambil keputusan, dan merealisasikan diri secara bertanggung jawab sehingga mencapai kebahagiaan dan kesejahteraan dalam kehidupannya (Permendikbud, 2014).

Keefektifan BK bergantung pada banyak faktor, tetapi salah satu faktor yang terpenting adalah relasi satu sama lain, dan saling mengerti antara konselor dan klien. BK yang merupakan sebuah perjumpaan kultural (Kartadinata, 2011, p. 59) harus mampu mendorong konselor untuk peka terhadap latar belakang klien dan kebutuhan khususnya, serta secara seimbang menyesuaikan diri dengan konsep nilai, bias dan kemampuan klien (Atkinson, 2004; Brinson, 1996; Holiday, Leach \& Davidson, 1994) (Mitchell, 2011). Guru BK/Konselor sebagai seorang psychoeducator harus kompeten, salah satunya dalam memahami kompleksitas interaksi individu-lingkungan dalam ragam konteks sosial budaya (Kartadinata, 2014, p. 7). Memahami perbedaan sosial budaya merupakan kemampuan mengembangkan kesadaran diri (self-awareness) dan mengembangkan kesadaran diri akan diri orang lain (awareness of others).

Guna memahami dan menghadapi perbedaan budaya, guru BK/konselor harus siap untuk belajar banyak hal dari budayanya sendiri dan budaya orang lain. Mempelajari budaya berarti mempelajari komunikasi karena mempelajari komunikasi dan budaya merupakan satu hal yang tidak dapat dipisahkan. Komunikasi dan budaya mempunyai hubungan timbal balik, seperti dua sisi mata uang (Lubis, 2002). Budaya menjadi bagian dari perilaku komunikasi dan pada gilirannya komunikasi pun turut menentukan memelihara, mengembangkan atau mewariskan budaya. Budaya dan komunikasi saat ini menurut Modiga (2014) merupakan binomial dengan istilah bergantian, dua proses terjalin dalam satu blok. Smith (1966) menerangkan hubungan yang tidak terpisahkan antara komunikasi dan kebudayaan yang kurang lebih sebagai 
berikut: Kebudayaan merupakan suatu kode atau kumpulan peraturan yang dipelajari dan dimiliki bersama; untuk mempelajari dan memiliki bersama diperlukan komunikasi, sedangkan komunikasi memerlukan kode-kode dan lambang-lambang yang harus dipelajari dan dimiliki bersama. Hubungan antara individu dan kebudayaan saling mempengaruhi dan saling menentukan. Kebudayaan diciptakan dan dipertahankan melalui aktifitas komunikasi para individu anggotanya. (Lubis, 2002, p. 9).

Komunikasi antarbudaya sering dipertukarkan dengan istilah komunikasi lintasbudaya (cross-cultural communication), atau komunikasi antar-etnik (interethnic communication), namun sebenarnya komunikasi antarbudaya lebih inklusif, karena tidak sekedar mempelajari antara dua kelompok etnik atau ras. Komunikasi antarbudaya merupakan istilah yang mencakup arti umum dan menunjukkan pada komunikasi antara orang-orang yang mempunyai latar belakang yang berbeda bangsa, ras, bahasa, agama, tingkat pendidikan, status sosial bahkan jenis kelamin intinya dari kebudayaan yang berbeda (Mulyana, 2010, p. v). Atau dengan kata lain komunikasi antarbudaya terjadi bila produsen pesan adalah anggota suatu budaya dan penerima pesannya adalah anggota suatu budaya lainnya (Samovar et al, 2003). Komunikasi antarbudaya kerap disandingkan dengan kompetensi antarbudaya. Dimana kompetensi antarbudaya didefinisikan sebagai "kemampuan untuk berkomunikasi secara efektif dan tepat dalam situasi antarbudaya berdasarkan satu pengetahuan antarbudaya, keterampilan, dan sikap" (Deardorff, 2006).

Komunikasi antar budaya memang mengakui dan mengurusi permasalahan mengenai persamaan dan perbedaan dalam karakteristik kebudayaan antar pelaku-pelaku komunikasi, tetapi titik perhatian utamanya tetap terhadap proses komunikasi individu-individu atau kelompok-kelompok yang berbeda kebudayaan dan mencoba untuk melakukan interaksi (Lubis, 2002). . Seluruh definisi diatas dengan jelas menerangkan bahwa ada penekanan pada perbedaan kebudayaan sebagai faktor yang menentukan dalam berlangsungnya proses komunikasi antar budaya. Dari berbagai konsep yang diuraikan, maka dapat disimpulkan bahwa "Komunikasi antarbudaya adalah kemampuan kognitif, afektif dan psikomotor pada seseorang untuk menyampaikan pesan secara efektif kepada orang lain yang berbeda nilai, norma dan adat istiadat".

Berkomunikasi dalam keragaman budaya seperti di masyarakat Indonesia, kerap kali menemui masalah atau hambatan-hambatan yang tidak diharapkan sebelumnya. Misalnya, dalam penggunaan bahasa, lambang-lambang, nilai atau 
norma-norma masyarakat dan sebagainya (Mulyana, 2010). Padahal syarat untuk terjalinnya hubungan komunikasi itu tentu harus ada saling pengertian dan pertukaran informasi atau makna antara satu dengan lainnya (Lubis, 2002). Jika tidak, akan menimbulkan efek radikal yang tidak baik antara masingmasing orang yang berbeda budaya (Mindess, 1999, p. 6). Contoh permasalahan yang sering muncul baik di perguruan tinggi maupun di kalangan masyarakat umum di antaranya kesulitan penyesuaian diri individu yang mengalami gegar budaya (culture shock) (Oberg, Kalvero in Hooves, David, 1972; Flanja, Delia, 2009) perbedaan bahasa (Henny, Rochayanti, dan Isbandi, 2011), sstereotip terhadap budaya tertentu, keterasingan (strangershood), dan ketidakpastian (uncertainty) (Sari, 2016). Sehingga berdasarkan permasalahan di atas dan bidang ilmu BK yang berperan sebagai proses perjumpaan budaya, maka peneliti tertarik untuk meneliti bagaimanakah profil komunikasi yang terjadi di kalangan mahasiswa BK sebagai calon konselor masa depan yang harus terampil dalam bidangnya dan harus memiliki kepekaan budaya.

\section{METODE}

Responden utama penelitian adalah mahasiswa Bimbingan dan Konseling (BK) di IKIP PGRI Pontianak. Dengan karakteristik; berjenis kelamin laki-laki dan perempuan, dan berasal dari latar belakang status social-ekonomi, suku dan agama yang berbeda-beda. Responden penelitian adalah mahasiswa dari setiap jenjang semester I, III dan V tahun akademik 2016/2017. Jumlah total responden sebanyak 66 orang.

Untuk mendapatkan data yang akurat maka dikembangkan instrumen berbentuk inventori dengan menggunakan skala Guttman. Yaitu skala yang digunakan untuk jawaban yang bersifat jelas (tegas) dan konsisten. Hanya ada dua interval yaitu "Ya atau Tidak". Adapun aspek dalam instrument yaitu tentang; 1) kemampuan kognitif, 2) kemampuan Afektif, dan 3) kemampuan psikomotor (dengan indikator; penyesuaian terhadap perbedaan nilai, pengungkapan terhadap perbedaan norma, dan pembiasaan terhadap perbedaan adat istiadat). Cara pengisian inventori yaitu mahasiswa diminta memberi tanda silang (X) pada pernyataan-pernyataan yang sesuai dengan keadaan dirinya.

Langkah-langkah penelitian yang dilakukan antara lain; peneliti melakukan komunikasi ke lapangan sasaran penelitian untuk mendapatkan informasi jadwal dan melakukan kesepakatan waktu dengan pihak-pihak yang dapat 
membantu pelaksanaan penelitian. Kemudian pemilihan kelas, jenjang semester, dan jumlah reponden dilakukan dengan ijin dan kerjasama dengan dosen-dosen yang mengampu matakuliah pada program studi Bimbingan dan Konseling (BK) di IKIP PGRI Pontianak. Sebagian inventori disebar oleh peneliti dan sebagian lainnya meminta bantuan dari dosen BK untuk menyebarkan inventori kepada mahasiswa. Dibutuhkan waktu selama 6 hari bagi peneliti dan dosen untuk menyebarkan inventori dikarenakan harus menyesuaikan dengan jadwal belajar para mahasiswa yang menjadi responden penelitian, setelah itu hasil pengisian inventori peneliti kumpulkan untuk diolah.

Penelitian ini menggunakan analisis statistic deskriptif. Hasil penelitian dianalisis dengan menggunakan rumus rata-rata untuk menentukan skor setiap etnis dalam aspek kognitif, afektif dan psikomotor. Dilanjutkan dengan melakukan uji komparasi atas profil komunikasi antarbudaya mahasiswa semester I, III dan V dilihat dari aspek kognitif, afektif dan psikomotor. Diawali dengan menggunkan uji Fisher (uji F) dan untuk mengetahui mana yang lebih baik, digunakan uji lanjut (komparasi ganda)

\section{HASIL DAN PEMBAHASAN}

Temuan penelitian dari hasil penyebaran inventori profil komunikasi antarbudaya yang telah diolah, menunjukkan bahwa secara umum skor profil komunikasi antarbudaya pada mahasiswa BK dilihat dari keseluruhan etnis yang ada dalam ketiga aspek ada pada Gambar 1.

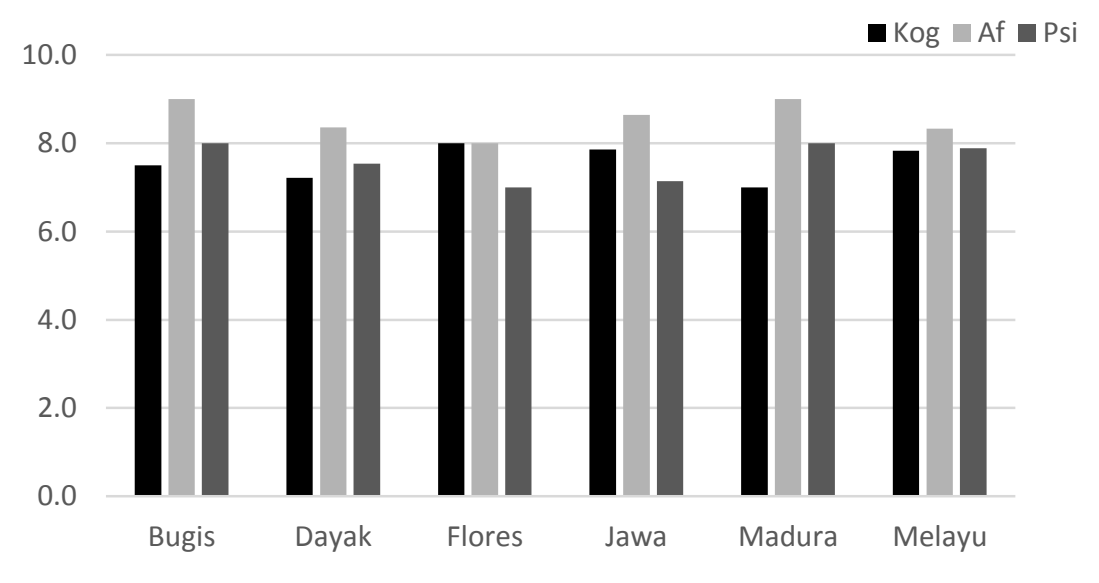

Gambar 1. Diagram Skor Profil Umum Komunikasi Antarbudaya Mahasiswa 
Diagram tersebut, adalah hasil penyebaran inventori berdasarkan pengelompokan etnis dan membandingkan setiap aspek yang ada yaitu aspek kognitif, afektif dan psikomotor. Dalam diagram 1 menunjukkan kemampuan ketiga aspek pada mahasiswa etnis Bugis Tinggi. Pada mahasiswa etnis Dayak, kemampuan pada aspek kognitif termasuk kategori baik, sedangkan pada dua aspek lainnya sangat baik. Kemampuan kognitif dan afektif mahasiswa dari etnis flores sangat baik, namun di aspek psikomotor masuk dalam kategori baik. Kemampuan kogntif mahasiswa dari etnis Jawa sama persis dengan mahasiswa dari etnis flores yaitu pada aspek kognitif dan afektif sangat baik, sedangkan pada aspek psikomotornya baik. Kategori kemampuan kognitif mahasiswa etnis Madura hanya pada kategori baik sedangkan dua aspek lainnya memiliki kategori sangat baik. Mahasiswa dari etnis Melayu dalam ketiga aspek sangat baik dibandingkan dengan perbandingan aspek pada etnis lain dan terlihat seimbang.

\section{Gambaran Profil Komunikasi Antarbudaya Mahasiswa BK Berdasarkan Jenis Kelamin}

Gambaran profil komunikasi antarbudaya mahasiswa BK berdasarkan perbedaan jenis kelamin adalah sangat baik seperti diperlihatkan pada Gambar 2.

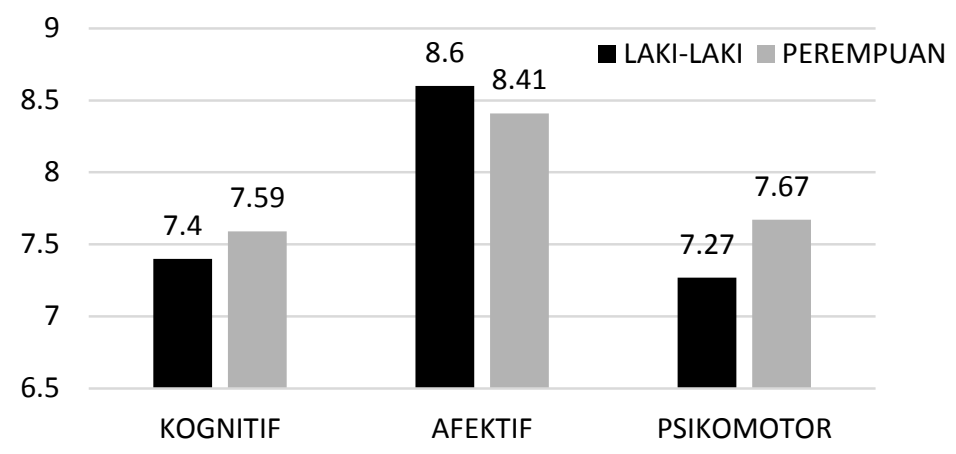

Gambar 2. Diagram Skor Profil Komunikasi Antarbudaya Mahasiswa Berdasarkan Jenis Kelamin

Gambar 2 menunjukkan bahwa profil komunikasi antarbudaya mahasiswa BK berdasarkan pada jenis kelamin tidak mengalami perbedaan yang mencolok dan semuanya menunjukkan hasil yang sudah sangat baik dalam hal ini. Sebagai perbandingan maka selanjutnya peneliti melakukan uji komparasi atas profil komunikasi antarbudaya mahasiswa semester I, III dan V dilihat dari aspek kognitif, afektif, dan psikomotor. Dikarenakan Kemampuan mahasiswa lakilaki berbeda dengan mahasiswa perempuan, maka dilanjutkan dengan uji lanjut, 
dengan hasil: $F_{K L-A L}=-0.0003788$. Dikarenakan $\mathrm{F}$ hitung $=-0.0003788$ lebih kecil dari F Tabel = 3,69 maka "Mahasiswa perempuan memiliki kemampuan yang lebih tinggi daripada mahasiswa laki-laki."

\section{Gambaran Profil Komunikasi Antarbudaya Mahasiswa BK Berdasarkan Jenjang Semester}

Skor profil komunikasi antarbudaya mahasiswa berdasarkan jenjang semester adalah sangat baik seperti ditunjukkan pada Gambar 3.

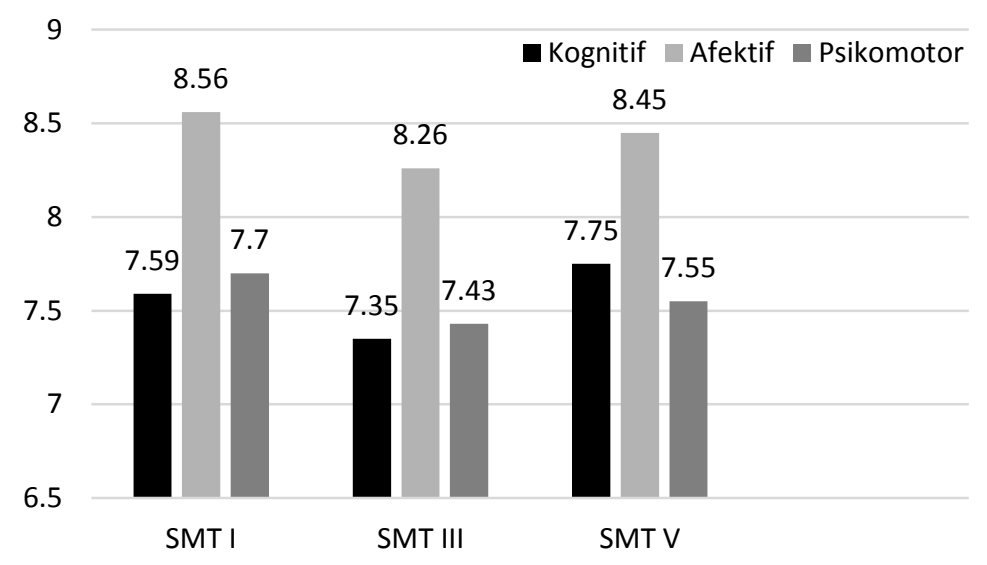

Diagram 3. Skor Profil Komunikasi Antarbudaya Mahasiswa Berdasarkan Jenjang Semester

Pada diagram 3 secara umum menunjukkan bahwa profil komunikasi antarbudaya mahasiswa berdasarkan jenjang semester sudah sangat baik pada semua jenjang. Tidak ada perbedaan besar, hanya terlihat bahwa aspek afektif memiliki nilai yang paling tinggi daripada aspek kognitif maupun psikomotor pada semua jenjang semester. Dan untuk melihat perbandingan ketiga jenjang semester itu, perhitungan dilanjutkan dengan melakukan uji komparasi atas profil komunikasi antarbudaya mahasiswa semester I, III dan V dilihat dari aspek kognitif, afektif dan psikomotor.

\section{Aspek Kognitif}

Hasil rangkuman analisis variansi tabel di atas untuk hasil angket pada JK (Jumlah Kuadrat) menunjukkan angka -36604.10 dibagi dengan dk (Derajat Kelas) sebesar 2, maka didapatkan RK (Rataan Kelas) sebesar -18302. Pada Galat (standar error) nilai JK Galat sebesar 1590.14457 dibagi dengan dk galat sebesar 63 maka didapatkan nilai RK sebesar 25.24. Sedaangkan F obs(nilai F hitung) sebesar -725.10954 didapatkan dari hasil pembagian antara RK angket dengan RK Galat, dan nilai F $\alpha$ (nilai $F$ tabel) sebesar 3,96 berarti $\mathrm{F}$ hitung $<\mathrm{F}$ 
tabel. Untuk mengetahui penilaian pada semester berapa yang lebih baik antara antara semester, dengn hasil: Aspek kognitif semester I lebih baik daripada aspek kognitif semester III $\left(F_{S 1-S 3}=0.3215509\right)$, aspek kognitif semester V lebih baik daripada aspek kognitif semester I $\left(F_{S 1-S 5}=0.0002133\right)$, dan Aspek kognitif semester V lebih baik daripada aspek kognitif semester III $\left(F_{S 3-S 5}=\right.$ $0.2584844)$.

\section{Aspek Afektif}

Hasil rangkuman analisis variansi tabel di atas untuk hasil angket pada JK (Jumlah Kuadrat) menunjukkan angka 56.72 dibagi dengan dk (Derajat Kelas) sebesar 2, maka didapatkan RK (Rataan Kelas) sebesar 28.359. Pada Galat (standar error) nilai JK Galat sebesar 112691.039 dibagi dengan dk galat sebesar 63 maka didapatkan nilai RK sebesar 1788.7. Sedaangkan F obs (nilai F hitung) sebesar 0.01585 didapatkan dari hasil pembagian antara RK angket dengan RK Galat, dan nilai $\mathrm{F} \alpha$ (nilai $\mathrm{F}$ tabel) sebesar 3,96 berarti $\mathrm{F}$ hitung $<\mathrm{F}$ tabel.

Dikarenakan tidak sama penilaian keseluruhan aspek pada masing-masing semester. Untuk mengetahui penilaian pada semester berapa yang lebih baik antara antara semester I, III dan V maka dilanjutkan dengan uji lanjut, menghasilkan: Aspek afektif semester I lebih baik daripada aspek afektif semester III $\left(F_{A 1-A 3}=0.0006030\right)$, Aspek afektif semester I lebih baik daripada aspek afektif semester $\mathrm{V}\left(F_{A 1-A 5}=0.0000626\right)$, dan aspek afektif semester $\mathrm{V}$ lebih baik daripada aspek kognitif semester III $\left(F_{A 3-A 5}=0.0001887\right)$.

\section{Aspek Psikomotor}

Hasil rangkuman analisis variansi tabel di atas untuk hasil angket pada JK (Jumlah Kuadrat) menunjukkan angka 42.72 dibagi dengan dk (Derajat Kelas) sebesar 2, maka didapatkan RK (Rataan Kelas) sebesar 21.36. Pada Galat (standar error) nilai JK Galat sebesar 91007.2193 dibagi dengan dk galat sebesar 63 maka didapatkan nilai RK sebesar 1444.6. Sedaangkan F obs(nilai F hitung) sebesar 0.01479 didapatkan dari hasil pembagian antara RK angket dengan RK Galat, dan nilai F $\alpha$ (nilai F tabel) sebesar 3,96 berarti F hitung < F tabel.

Dikarenakan tidak sama penilaian keseluruhan aspek pada masing-masing semester. Untuk mengetahui penilaian pada semester berapa yang lebih baik antara antara semester I, III dan V maka dilanjutkan dengan uji lanjut, menghasilkan: Aspek psikomotor semester I lebih baik daripada semester III $\left(F_{P 1-P 3}=0.0006218\right)$, Aspek psikomotor semester I lebih baik daripada 
semester V $\left(F_{P 1-P 5}=0.0001643\right)$, dan Aspek psikomotor semester V lebih baik daripada semester III $\left(F_{P 3-P 5}=0.0000867\right)$.

\section{Komunikasi Antarbudaya Mahasiswa BK di Pontianak}

Pontianak merupakan salah satu kota di Provinsi Kalimantan Barat yang merupakan salah satu provinsi yang memiliki beragam etnis penduduknya. Seperti yang telah dijelaskan sebelumnya, berkomunikasi dalam keragaman budaya seperti salah satunya di Kalimantan Barat ini dapat menimbulkan berbagai permasalahan dan kerawanan konflik. Dikarenakan berbagai sebab sepele sampai berat (Kristianus, 2009, p. 33; Iskandar \& Dadan, 2004, p. 131), perbedaan budaya menjadi jurang khususnya dalam komunikasi antarbudaya yang pada akhirnya menimbulkan stereotip pada suku/etnis tertentu hingga saat ini. Komunikasi seharusnya dapat menjembatani komunikasi antar etnis (Condon \& Sailo, 1976). Hal ini mengandung makna bahwa tanpa komunikasi manusia akan sulit memenuhi kebutuhannya dan terisolasi (Samovar et al, 2003, p. 12). Komunikasi yang dilakukan manusia merupakan kebutuhan berinteraksi/kontak sosial, yaitu keinginan dasar untuk menciptakan kebutuhan psikologis akan teman. Orang-orang yang menginginkan banyak teman akan mempelajari keterampilan-keterampilan sosial untuk mencari teman (Reiss, 2008, p. 50).

Penelitian yang dilakukan ini juga merupakan salah satu upaya untuk mendeskripsikan bagaimana kondisi komunikasi antarbudaya, terutama pada mahasiswa di kota Pontianak. Profil dalam penelitian ini didefinisikan sebagai grafik atau ikhtisar yang memberikan fakta tentang hal-hal khusus (KBBI, 2016). Maka dapat diartikan bahwa penelitian ini menampilkan dan menjelaskan grafik atau ikhtisar mengenai fakta-fakta tentang kemampuan kognitif, afektif dan psikomotor seorang individu dalam proses penyampaian pesan kepada individu lain yang berbeda nilai, norma dan adat istiadatnya. Hasil temuan peneliti tentang profil komunikasi mahasiswa IKIP PGRI Pontianak pada bulan desember 2016 menunjukkan bahwa untuk lingkungan kota Pontianak, komunikasi antar budaya masih berlangsung dalam keadaan kondusif. Seperti yang dijelaskan pada temuan di atas secara umum komunikasi antarbudaya mahasiswa kesemuanya menunjukkan hasil yang baik bahkan sangat baik.

Responden yang dijadikan objek penelitian adalah mahasiswa Bimbingan dan Konseling (BK) pada IKIP PGRI Pontianak dari semua jenjang semester. Mahasiswa adalah subjek utama dan merupakan bagian penting dalam sebuah 
lembaga pendidikan tinggi, yang tentunya memberikan kontribusi besar terhadap kemajuan lembaga tempatnya menempuh pendidikan. Profil komunikasi antarbudaya mahasiswa BK berdasarkan perbedaan jenis kelamin secara umum sudah sangat baik, kemudian peneliti melakukan proses perbandingan dengan melakukan uji komparasi dan menunjukkan hasil bahwa "mahasiswa perempuan memiliki kemampuan komunikasi (dalam aspek kognitif, afektif dan psikomotor) yang lebih tinggi daripada mahasiswa lakilaki”. Hal ini bertentangan dalam beberapa kebudayaan, dimana laki-laki selalu mendominasi wanita, terutama budaya yang menganut maskulinitas. Pandangan dunia terhadap hal ini juga tidak terbantahkan, dimana hampir semua bidang didominasi oleh kaum laki-laki seperti olah raga, karir, militer, bahkan dalam kehidupan pribadi dalam rumah tangga. Pandangan ini mulai luntur setelah adanya isu emansipasi atau gender berkembang. Mengenai perbandingan gaya komunikasi antara dua budaya yang berbeda yakni budaya maskulin (pria) dan budaya feminim (wanita), tidak menunjukkan bahwa cara berkomunikasi pria lebih baik daripada cara berkomunikasi wanita atau sebaliknya. Namun perbedaan gaya komunikasi tersebut dapat diamati melalui beberapa kategorikategori tertentu, seperti perbedaan saat berbicara, pemilihan topik pembicaraan, cara interupsi, penggunaan kata atau kalimat tanya, menggunakan cerita dan guyonan, dan kategori-kategori lainnya (Juliano, 2015)

Sementara itu, profil komunikasi antarbudaya mahasiswa BK berdasarkan perbedaan jenjang semester secara umum juga sudah sangat baik, namun dari hasil pembandingan ketiga jenjang menunjukkan hasil bahwa " aspek kognitif pada mahasiswa semester V lebih baik dibandingkan mahasiswa mahasiswa semester I dan III, aspek afektif mahasiswa semester V lebih baik dibandingkan mahasiswa mahasiswa semester I yang lebih baik daripada mahasiswa semester III dan V, sedangkan pada aspek psikomotor mahasiswa semester I lebih baik daripada mahasiswa semester III dan V". Meskipun demikian, hal ini tidak memperlihatkan perbedaan yang mendasar dan hasil ini tidak berpengaruh buruk pada komunikasi antarbudaya mahasiswa.

Ketiga aspek di atas (kognitif, afektif dan psikomotor) sebagai kemampuan yang selalu ada dalam proses komunikasi. Salah satu riset menunjukkan bahwa dimensi afektif dan perilaku terkait dengan kepuasan mahasiswa terhadap keterampilan komunikasi mereka, berbicara merupakan faktor paling penting dalam persepsi kompetensi komunikasi dan menyesuaikan diri dengan kehidupan (Zimmermann, 1995.). kemudian ada juga riset sejenis yang 
menganalisis paper (tugas makalah) reflektif dari 18 mahasiswa yang kembali dari program pendidikan luar negeri di university in the southeast of the United States, menunjukkan bahwa pengalaman di luar negeri memiliki dampak yang jelas pada kognitif, afektif, dan keterampilan perilaku mahasiswa, membantu untuk mengembangkan tingkat yang lebih dalam pada kompetensi antarbudaya (Root \& Ngampornchai, 2013).

Kedua riset di atas menunjukkan bahwa aspek kognitif, afektif maupun psikomotor merupakan aspek penting dalam komunikasi antarbudaya. Komunikasi antarbudaya adalah proses dinamis, yang melibatkan perpindahan dari satu ruang budaya ke yang lain. Kompetensi komunikasi antarbudaya tidak membatasi diri hanya untuk budaya, tetapi melibatkan kognitif, afektif, adaptasi operasional dari sistem inner dari seorang individu untuk semua sistem komunikasi antarbudaya (Pricope, 2016).

Samovar et al (2003) menyatakan pada kebanyakan situasi, para pelaku interaksi antarbudaya tidak menggunakan bahasa yang sama, tetapi bahasa dapat dipelajari dan masalah komunikasi yang lebih besar terjadi dalam area verbal maupun nonverbal. Khususnya, komunikasi nonverbal sangat rumit, multidimensional, dan biasanya merupakan proses yang spontan. Orang-orang tidak sadar akan sebagian besar perilaku nonverbalnya sendiri, yang dilakukan tanpa berpikir, spontan, dan tidak sadar (Seob, 2014).

Riset pada beberapa etnis menunjukkan bahwa beberapa faktor yang mempengaruhi komunikasi antarbudaya adalah mengenai perbedaan bahasa, kesalahpahaman nonverbal (seperti gesture, suara dan sebagainya) (Juariyah, 2012) serta dalam persepsi mereka dalam menilai antar etnis/suku (Febriyanti, 2014; Siregar, 2015), sehingga kadang menyebabkan culture shock (Flanja, 2009) terutama di kalangan mahasiswa yang baru pindah (Hendrastomo, 2015). Namun ada juga riset yang membuktikan bahwa perbedaan bukanlah jurang pemisah antara budaya yang satu dan lainnya (Heryadi \& Silvana, 2013), bahkan merupakan kebersamaan dalam keragaman (Pakpahan, 2013), dan mendorong perilaku individu menjadi positif dalam pandangan dunianya (Lubis, 2012).

Adapun aspek penting dalam instrument penelitian ini yaitu: 1) kemampuan kognitif (dengan indicator; pengetahuan terhadap perbedaan nilai, pemahaman terhadap perbedaan norma, dan penilaian terhadap perbedaan adat istiadat), 2) kemampuan Afektif (dengan indikator; penerimaan terhadap perbedan nilai, penghargaan terhadap perbedaan norma, dan perhatian terhadap adat istiadat), 
3) kemampuan psikomotor (dengan indikator; penyesuaian terhadap perbedaan nilai, pengungkapan terhadap perbedaan norma, dan pembiasaan terhadap perbedaan adat istiadat). Hal ini berlandaskan pada beberapa konsep, bahwa "komunikasi antar budaya sebagai kompetensi komunikasi yang bukan hanya berurusan dengan budaya tertentu, tetapi kognitif, afektif, dan kemampuan beradaptasi dalam semua konteks komunikasi antar budaya (Kim \& Korzenny, 1991, p. 259) (Franklin, 2009). Wiseman (1993) mengidentifikasi empat komponen dasar dari kompetensi komunikasi antarbudaya, yaitu: motivasi, pengetahuan, sikap dan perilaku (Martin \& Nakayama, 2012). Setiap ilmuwan menjabarkan ke empat komponen tersebut ke penjelasan yang lebih mendetil. Untuk dapat mahir berkomunikasi antarbudaya harus melalui tahapan awareness, knowledge dan skills (Hofstede, 2001).

Samovar et al (2003) menyatakan bahwa dalam proses komunikasi antarbudaya ada unsur-unsur yang sangat menetukan bekerja dan berfungsi secara terpadu bersama-sama, karena masing-masing saling berkaitan dan membutuhkan, unsur-unsur tersebut adalah: Sistem keyakinan, nilai dan sikap; pandangan hidup tentang dunia serta organisasi sosial (Sendjaja, 2004). Komunikasi antar budaya mengantarkan individu pada kesamaan perlakuan bagi individu dari berbagai budaya untuk saling mengenal dan berinteraksi.

\section{SIMPULAN}

Kompetensi komunikasi antarbudaya menekankan bahwa orang yang kompeten harus tahu, tidak hanya bagaimana berinteraksi secara efektif dan tepat dengan orang-orang dan lingkungan, tetapi juga bagaimana untuk memenuhi tujuan komunikasi mereka sendiri dengan menghormati dan menegaskan identitas budaya dari orang-orang yang berinteraksi dengan mereka. Komunikasi antarbudaya merupakan salah satu upaya meningkatkan hubungan baik antara konselor dan klien dalam proses bimbingan maupun konseling agar lebih optimal. Gambaran profil komunikasi antarbudaya mahasiswa BK yang telah dijabarkan dalam aspek kognitif, afektif dan psikomotor dilihat dari perbedaan jenis kelamin maupun jenjang semester menunjukkan hasil yang sudah sangat baik, ini merupakan suatu kondisi yang harus tetap dilestarikan dan dikembangkan agar proses BK selalu merupakan kegiatan yang mampu menyatukan persepsi dalam keberagaman budaya bagi bangsa Indonesia dan bagi mahasiswa khususnya sebagai generasi penerus bangsa ini. 
Bimbingan dan Konseling lintas budaya atau antarbudaya melibatkan konselor dan klien yang berasal dari latar belakang budaya yang berbeda, karena itu proses konseling sangat rawan terjadinya bias-bias budaya pada pihak konselor yang mengakibatkan konseling tidak berjalan efektif. Agar berjalan efektif, maka konselor dituntut untuk memiliki kepekaan budaya dan melepaskan diri dari bias-bias budaya, mengerti dan dapat mengapresiasi diversitas budaya, dan memiliki keterampilan-keterampilan yang responsive secara kultural. Karena pertumbuhan yang tak terelakkan dari keberagaman di masyarakat saat ini, guru perlu dipersiapkan dan dilatih untuk menjadi kompeten dalam budaya, untuk secara efektif terlibat dengan perbedaan latar belakang antara semua siswa. Keterlibatan guru, khususnya guru BK dan siswa membutuhkan komunikasi yang efektif dan pengakuan dari berbagai cara di mana orang memahami dan menafsirkan perbedaan budaya. Ini berarti bahwa perlu untuk menggabungkan kompetensi antarbudaya ke dalam sistem pendidikan dalam rangka mengurangi kesenjangan ini.

Konflik antarbudaya dewasa ini disebabkan antara lain tidak adanya atau kurangnya pemahaman dan penghargaan atas budaya orang lain, maka salah satu usaha untuk menanggulangi konflik tersebut adalah dengan mendidik manusia-manusia Indonesia, khususnya generasi muda sebagai calon pemimpin bangsa, untuk menjadi manusia-manusia antarbudaya. Melalui pendidikan ini kita dapat menciptakan generasi-generasi baru yang tidak terkungkung oleh perspektif nasional, rasial, etnik, dan territorial.

Para pendidik sebaiknya menguasai kompetensi komunikasi antarbudaya dalam mendidik, yang terbagi menjadi 2 komponen yaitu individual dan kontekstual. Komponen individual terdiri dari: Motivasi, yaitu keinginan atau dorongan untuk berkomitmen dalam hubungan, untuk belajar tentang diri pribadi dan orang lain, serta berusaha untuk fleksibel. Pengetahuan tentang diri sendiri, yaitu mengenal kelebihan dan kekurangan diri sebagai komunikator. Pengetahuan bahasa, yaitu pengetahuan tentang bahasa ibu, bahasa asing dan tahu kesulitan-kesulitannya. Sikap, termasuk toleran terhadap makna ambigu, empati dan tidak berprasangka buruk. Sedangkan komponen kontekstual terdiri dari: Pemahaman atas konteks dan setting dimana komunikasi berlangsung dan mengetahui posisi kita sebagai komunikator di dalam suatu percakapan/pertemuan atau situasi.

Selain itu, para pendidik juga dapat melakukan pengembangan riset tentang keragaman budaya yang turut mempengaruhi pelaksanaan BK agar mampu 
meningkatkan kesadaran diri (Kesadaran bias, nilai-nilai, dan keyakinan), kemampuan kognitif dan emosional, dan kemampuan untuk mengekspresikan diri melalui instrument, penanaman kompetensi budaya dan advokasi dalam BK.

\section{REFERENSI}

Condon, J. C., \& Sailo, M. (1976). Communicsting across cultures for what? In D. Mulyana, \& J. Rakhmat, Komunikasi Antar Budaya (pp. 1-10). Bandung: Remaja Rosdakarya.

Deardorff, D. K. (2006). Identification and assessment of intercultural competence as a student outcome of internationalization. Journal of studies in international education, 10(3), 241-266.

Febriyanti, F. (2014). Hambatan komunikasi antarbudaya masyarakat suku flores dan lombok di desa bukit makmur kecamatan kaliorang kabupaten kutai timur. Ejournal Ilmu Komunikasi, 2(3), 453-463.

Flanja, D. (2009). Culture shock in intercultural communication. Studia Universitatis Babes-Bolyai-Studia Europaea, (4), 107-124.

Heryadi, H., \& Silvana, H. (2013). Komunikasi antarbudaya dalam masyarakat multikultur. Jurnal Kajian Komunikasi, 1(1), 95-108.

Hendrastomo, M. D. (2015). Fenomena culture shock (gegar budaya) pada mahasiswa perantauan di Yogyakarta. Jurnal Pendidikan Sosiologi , 1-15

Hofstede, G. (2001). Culture's consequences: Comparing values, behaviors, institutions and organizations across nations. Sage.

Iskandar, D. (2004). Identitas budaya dalam komunikasi antar-budaya: Kasus etnik madura dan etnik dayak. Jurnal Masyarakat Dan Budaya, 6(2), 119140 .

Juariyah. (2012). Miskomunikasi antarbudaya mahasiswa pendatang di kabupaten Jember. Jurnal Ilmu Komunikasi, 10(3), 251-261.

Kartadinata, S. (2011). Menguak tabir bimbingan dan konseling sebagai upaya pedagogis. Bandung: UPI Press.

Kartadinata, S. (2014). Politik jati diri: Telaah filosofi dan praksis pendidikan bagi penguatan jati diri bangsa. Bandung: Universitas Pendidikan Indonesia.

KBBI. (2016). Kamus bahasa Indonesia online. Indonesia: http://kamusbahasaindonesia.org. 
Lubis, L. A. (2002). Komunikasi antar budaya. Sumatera Utara: USU digital library.

Lubis, L. A. (2012). Komunikasi antarbudaya etnis tionghoa dan pribumi di kota medan. Jurnal Ilmu Komunikasi, 10(1), 13-27

Martin, J. N., Nakayama, T. K., \& Carbaugh, D. (2012). The history and development of the study of intercultural communication and applied linguistics. The Routledge Handbook of Language and Intercultural Communication, 17-36.

Mindess, A. (1999). Between the sign: Intercultural communication for sign language interpreters. USA: Intercultural Press, a Nicholas Brealey Publishing.

Mitchell, R. L. (2011). Bimbingan dan konseling. Edisi 7. Yogyakarta: Pustaka Pelajar.

Modiga, G. (2014). Intercultural communication. EIRP Proceedings, 9, 284290.

Mulyana, D. (2010). Komunikasi antarbudaya: Panduan berkomunikasi dengan orang-orang berbeda budaya. Bandung: Remaja Rosdakarya.

Root, E., \& Ngampornchai, A. (2013). "I Came Back as a New Human Being" Student Descriptions of Intercultural Competence Acquired Through Education Abroad Experiences. Journal of Studies in International Education, 17(5), 513-532.

Pakpahan, F. B. (2013). Fungsi komunikasi antar budaya dalam prosesi pernikahan adat batak di kota Samarinda (Studi kasus empat pasangan berbeda etnis antara etnis batak dengan etnis jawa, toraja, dan dayak). Journal Ilmu Komunikasi, 1(3), 234-248.

Permendikbud. (2014). Permendikbud no. 111 tahun 2014 tentang bimbingan dan konseling pada pendidikan dasar dan menengah. Jakarta: Sekretariat Negara.

Juliano, S. (2015). Komunikasi dan gender: Perbandingan gaya komunikasi dalam budaya maskulin dan feminim. Jurnal Ilmu Politik dan Komunikasi, 5(1), 19-30.

Pricope, M. (2016). The intercultural speaker's competences. Euromentor Journal, 7(2), 94-101.

Rasyidin, W. (2014). Pedagogik: Teoritis dan praktis. Bandung: Remaja Rosdakarya.

Reiss, S. (2008). The normal personality. New York: Cambridge University Press. 
Sadulloh, U. (2015). Pedagogik (Ilmu mendidik). Bandung: Alfabeta.

Samovar, L. A., Porter, R. E., McDaniel, E. R., \& Roy, C. S. (2003). Intercultural communication: A reader. Cengage Learning.

Sari, F. N. (2016). Dinamika komunikasi antarbudaya di kalangan mahasiswa FISIP USU dalam menjaga harmonisasi. Jurnal USU.

Sendjaja, D. S. (2004). Teori komunikasi. Jakarta: Pusat Penerbitan Universitas Terbuka.

Seob, K. G. (2014). Komunikasi antara budaya Korea dan Indonesia. Kajian tentang perilaku masyarakat Korea dan Jawa. Yogyakarta: Pusat Studi Kore UGM.

Siregar, L. Y. (2015). Perspektif psikologi dalam komunikasi lintas budaya. Tasâmuh, 12(2), 115-129.

Spencer-Oatey, H., \& Franklin, P. (2009). Intercultural interaction: A multidisciplinary approach to intercultural communication. New York: Palgrave Macmillan.

Zimmermann, S. (1995). Perceptions of intercultural communication competence and international student adaptation to an American campus. Communication Education, 44(4), 321-335. 